\title{
LOCAL PRODUCTION OF $\mathrm{O}_{2}-$ BY NAD(P)H OXIDASE IN THE SARCOPLASMIC RETICULUM OF CORONARY ARTERIAL MYOCYTES: CADPR-MEDIATED Ca²+ REGULATION
}

\author{
Fan Zhang, Si Jin, Fan Yi, Min Xia, William L. Dewey, and Pin-Lan Li \\ Department of Pharmacology \& Toxicology, Medical College of Virginia, Virginia Commonwealth \\ University, VA 23298
}

\begin{abstract}
The present study was designed to determine whether the sarcoplasmic reticulum (SR) could locally produce superoxide $\left(\mathrm{O}_{2} \cdot{ }^{-}\right)$via $\mathrm{NAD}(\mathrm{P}) \mathrm{H}$ oxidase (NOX) in coronary arterial myocytes (CAMs) and to address whether cADPR-RyR/Ca ${ }^{2+}$ signaling pathway regulates this local $\mathrm{O}_{2}{ }^{--}$production from the SR. Using confocal microscopic imaging analysis in intact single CAMs, a cell-permeable indicator $\mathrm{CM}-\mathrm{H}_{2} \mathrm{DCFDA}$ for dynamic changes in intracellular ROS (in green color) and a highly selective ER-Tracker ${ }^{\mathrm{TM}}$ Red dye for tracking of the SR were found co-localized. A quantitative analysis based on the intensity of different spectra demonstrated a local $\mathrm{O}_{2}{ }^{-}$production derived from the SR. $\mathrm{M}_{1}$-receptor agonist, oxotremorine (Oxo) and a $\mathrm{Ca}^{2+}$ ionophore, A23187 time-dependently increased this $\mathrm{O}_{2}{ }^{--}$production colocalized with the SR. NOX inhibitors, diphenylene iodonium (DPI) and apocynin (Apo), or superoxide dismutase (SOD) and catalase, and Nox4 (a major intracellular NOX subunit) siRNA all substantially blocked this local production of $\mathrm{O}_{2}{ }^{-}$, demonstrating an involvement of NOX. This SR-derived $\mathrm{O}_{2}{ }^{-}$production was also abolished by the inhibitors of cyclic ADP-ribose (cADPR)-mediated $\mathrm{Ca}^{2+}$ signaling, such as nicotinamide (Nicot, $6 \mathrm{mM}$ ), ryanodine (Rya, $50 \mu \mathrm{M})$ or 8-Br-cADPR $(30 \mu \mathrm{M})$. However, IP 3 antagonist, 2-APB $(50 \mu \mathrm{M})$ had no effect. In CAMs transfected with siRNA of ADP-ribosyl cyclase or RyR, this $\mathrm{SR}_{2}{ }^{-}$production was attenuated. Electron spin resonance (ESR) spectromic assay in purified SR also demonstrated the production of $\mathrm{O}_{2}{ }^{-}$that was dependent on NOX activity and $\mathrm{Ca}^{2+}$ concentrations. These results provide direct evidence that $\mathrm{O}_{2}{ }^{-}$could be locally produced via NOX on the SR and that this local $\mathrm{O}_{2} \cdot-$ producing system is controlled by cADPR-RyR/Ca ${ }^{2+}$ signaling pathway.
\end{abstract}

\section{Keywords}

Redox signaling; coronary circulation; second messenger; vascular smooth muscle; nucleotides; ADP-ribose

Send Correspondence and Reprint Requests to: Pin-Lan Li, MD, Ph.D., Department of Pharmacology and Toxicology, Medical College of Virginia, Virginia Commonwealth University, 410 North $12^{\text {th }}$ Street, P.O. Box 980613, Phone: (804) 828-4793, Fax: (804) 828-2117, E-mail: E-mail: pli@vcu.edu.

Publisher's Disclaimer: This is a PDF file of an unedited manuscript that has been accepted for publication. As a service to our customers we are providing this early version of the manuscript. The manuscript will undergo copyediting, typesetting, and review of the resulting proof before it is published in its final citable form. Please note that during the production process errors may be discovered which could affect the content, and all legal disclaimers that apply to the journal pertain. 


\section{INTRODUCTION}

$\mathrm{NAD}(\mathrm{P}) \mathrm{H}$ oxidase (NOX) has been reported to be one of major sources of reactive oxygen species (ROS) in the vasculature[1-3]. This vascular redox regulatory enzyme is of characteristics of phagocyte NOX, which is composed of two transmembrane-bounded catalytic proteins of gp91 phox and p22 phox , and three cytosol-associated subunits of $\mathrm{p} 47^{\text {phox }}$, $\mathrm{p} 67^{\text {phox }}$ and $\mathrm{p} 40^{\text {phox }}$. In addition to gp91 phox named as Nox2, some other homologues of gp91 ${ }^{\text {phox }}$ such as Nox 1 , Nox 4 and Nox 5 were identified in the vascular cells such as endothelial and smooth muscle cells [3,4]. NOX is now well accepted as an important enzyme that produces $\mathrm{O}_{2}{ }^{-}$in the vasculature under physiological and pathological conditions to exert redox regulatory action on vascular function or to produce pathogenic responses.

In vascular smooth muscle cells (VSMCs), many studies have demonstrated that $\mathrm{O}_{2}{ }^{-}{ }^{-}$is accumulated when NOX is activated [1-3]. This intracellular accumulation of $\mathrm{O}_{2} \cdot{ }^{-}$led to an assumption that a plasma membrane-bound NOX may produce and release $\mathrm{O}_{2}{ }^{--}$into cells, which is different from the orientation of phagocyte NOX [1]. However, the topologic analysis has indicated that membrane-associated NOX should not release $\mathrm{O}_{2}{ }^{-}$into cytosol [5]. Recent studies on subcellular localization of vascular NOX have also demonstrated that $\mathrm{O}_{2} \cdot{ }^{-}$within VSMCs may not be derived from plasma membrane NOX (mNOX), but rather from intracellular compartmental NOXs[3,6,7]. We have recently reported that mNOX in VSMCs produced $\mathrm{O}_{2}{ }^{-}$in autocrine or paracrine producing manner when the cells were exposed to different agonists [7]. Using purified sarcoplasmic reticulum (SR) from coronary arterial myocytes (CAMs), we also demonstrated that an NOX is present on the SR, and this oxidase locally activates the cyclic ADP - ribose (cADPR) - sensitive ryanodine receptors/ $\mathrm{Ca}^{2+}(\mathrm{RyR} /$ $\mathrm{Ca}^{2+}$ ) release channels [3]. cADPR is a novel $\mathrm{Ca}^{2+}$ mobilizing second messenger, which is capable of inducing $\mathrm{Ca}^{2+}$ release from the SR via activation of RyR in CAMs[8-12].

Oxotremorine, a specific $\mathrm{M}_{1} \mathrm{mAChR}$ agonist, has been demonstrated to stimulate ADPribosylcyclase activity (CD38) and increase production of cADPR in vascular smooth muscle cells $[13,14]$. However, so far it is unknown how the SR NOX system associates with cADPR$\mathrm{RyR} / \mathrm{Ca}^{2+}$ signaling pathway in these smooth muscle cells.

The present study was designed to address these questions. First, we directly measured the dynamic changes in ROS production in intact CAMs by confocal microscopy using CM$\mathrm{H}_{2}$ DCFDA as a cell-permeable green indicator for ROS and a highly selective ER-Tracker ${ }^{\mathrm{TM}}$ red dye for labeling of the SR. A spectrum-based analysis was used to differentiate ROS production derived from the SR or other sources when these cells were stimulated by M1agonist. Second, we examined the role of $\mathrm{NOX}$ in $\mathrm{O}_{2}{ }^{-}$production from the SR by using its inhibitors and siRNA of Nox4. To explore the mechanism regulating this SR NOX activity, we tested whether this enzyme is controlled by local $\mathrm{Ca}^{2+}$ level and corresponding $\mathrm{Ca}^{2+}$ signaling molecules. Using electron spin resonance (ESR) spectrometry, the sensitivity of the SR NOX was analyzed to further determine the $\mathrm{Ca}^{2+}$ regulation of NOX activity on the SR.

\section{MATERIALS AND METHODS}

\section{Isolation and culture of CAMs}

The bovine CAMs were cultured as described previously [14-16]. In brief, bovine intramyocardial coronary arteries from left anterior descending artery were dissected and rinsed with 5\% FBS in medium 199 containing $25 \mathrm{mM}$ HEPES with $1 \%$ penicillin, $0.3 \%$ gentamycin, and $0.3 \%$ nystatin. The arterial lumen was filled with $0.4 \%$ collagenase in medium 199 . After 30 min of incubation at $37^{\circ} \mathrm{C}$, the arteries were flushed with medium 199 to denude the endothelium. The strips of denuded arteries were then cut into small pieces and placed into gelatin-coated flasks with medium 199 containing 10\% FBS with 1\% L-glutamine, $0.1 \%$ tyrosin, and $1 \%$ penicillin-streptomycin for 3-5 days until CAMs migration to the flasks. Once 
growth was established, the arteries were removed and cells were continuously grown in medium 199 containing 20\% FBS. The identification of CAMs was based on positive staining by an anti- $\alpha$-actin antibody. All studies were performed with cells of passage of 2-4.

\section{Confocal fluorescent microscopic detection of ROS localized around the SR in CAMs}

Intracellular ROS production around the SR was monitored by their trapping with 5-(and-6)chloromethyl-2', 7'-dichlorodihydrofluorescein diacetate, acetyl ester (CM- $\left.\mathrm{H}_{2} \mathrm{DCFDA}\right)$ and simultaneous labeling of the SR by ER-Tracker ${ }^{\mathrm{TM}}$ red dye using confocal laser scanning microscopy [7]. Subconfluent CAMs plated on the $\Phi 35 \mathrm{~mm}$ cell culture plates were washed for three times with Hanks' buffered saline solution (HBSS) that contains (in mM): $137 \mathrm{NaCl}$, $5.4 \mathrm{KCl}, 4.2 \mathrm{NaHCO}_{3}, 3 \mathrm{Na}_{2} \mathrm{HPO}_{4}, 0.4 \mathrm{KH}_{2} \mathrm{PO}_{4}, 1.5 \mathrm{CaCl}_{2}, 0.5 \mathrm{MgCl}_{2}, 0.8 \mathrm{MgSO}_{4}, 10$ glucose, 10 HEPES (pH 7.4), then incubated at $37^{\circ} \mathrm{C}$ with $5 \% \mathrm{CO}_{2}$ in the same HBSS buffer containing $1 \mu \mathrm{M}$ ER-Tracker ${ }^{\mathrm{TM}}$ red dye for $15 \mathrm{~min}$, followed by adding ROS detection agent CM- $\mathrm{H}_{2}$ DCFDA to a final concentration of $1 \mu \mathrm{M}$ and continuing to incubate for another 15 min. To examine the effects of $\mathrm{O}_{2}{ }^{-}$scavengers, $\mathrm{NAD}(\mathrm{P}) \mathrm{H}$ oxidase inhibitor, ADP-ribosyl cyclase antagonist, or the $\mathrm{SR} \mathrm{Ca}^{2+}$ release channel blockers on the Oxotremorine(Oxo)-induced intracellular ROS production, CAMs loaded with both dyes were pretreated with polyethyleneglycol (PEG)-conjugated $\mathrm{O}_{2}{ }^{-}$dismutase (PEG-SOD; 200U/ml) [17] plus polyethylene-glycol (PEG)-conjugated catalase (CA; $200 \mathrm{U} / \mathrm{ml})$ [18], diphenylene iodonium (DPI; $50 \mu \mathrm{M}$ ), ryanodine (Ryr; $50 \mu \mathrm{M})$ or 8 -Br-cADPR $(30 \mu \mathrm{M})$ for $15 \mathrm{~min}$, respectively in different groups of cells and then Oxo-induced ROS production was re-determined. Confocal fluorescent microscopic images were acquired by an Olympus Fluoview System (version 4.2, FV300), which consists of an Olympus BX61WI inverted microscope with an Olympus Lumplan F1 $\times 60,0.9$ numerical aperture, and water-immersion objective. Real-time ROS generation was detected as a result of $\mathrm{H}_{2} \mathrm{DCF}$ oxidation (Green image) by a single z-section, or $0.1-\mu \mathrm{m}$ sections with excitation and emission wavelengths of 488 and $515 \mathrm{~nm}$, and the staining of SR (Red image) was simultaneously recorded at excitation/emission of 587/615 $\mathrm{nm}$. The subcellular source of ROS was determined by overlaying the ROS green image and SR organelle red image and then the merged images were analyzed off line by using co-localization function of Image Pro-Plus software. For each group of images, the intensity of different color spectrum areas was quantitated. Yellow spots were considered as ROS co-localized around the SR relative to green areas that represent intracellular global ROS or ROS from other resources. The relative fluorescence intensity to basal level before any stimuli was used as normalized fluorescence intensity to present the production of ROS.

\section{RNA interference of Nox4, ADP-ribosyl cyclase and $\mathrm{Ryr} / \mathrm{Ca}^{2+}$ receptor in CAMs}

In addition to pharmacological intervention, RNA interference was also performed to silence the genes coding NOX subunits dominantly expressed in the SR, Nox4, ADP-ribosyl cyclase and ryanodine receptor 2 (RyR2) in CAMs to further demonstrate that NOX is responsible for the local $\mathrm{O}_{2} \cdot-$ production around the SR and cADPR/RyR Ca ${ }^{2+}$ signaling pathway in the regulation of SR NOX activity. Three pairs of small inhibitory RNA (siRNA) for each gene were chosen using QIAGEN siRNA design program and synthesized and double-stranded by Xeragon. These pairs of siRNA were tested for knocking down specific gene to find a most efficient pair of siRNA for our experimental protocols. A scrambled RNA or Xeragon library scrambled RNA was synthesized for negative control. The most effective pair of siRNA for targeting CD38 (NM_175798) consisted of AAGCGATCAGGCAGGCATTCA and its countpartner; for RyR2 (XM_617538) was AACTGCCAGAGCCAGTAAAAT; and for Nox4 (XM_614713) was AAGACCTGGCCAGTATATATTAT. siRNA transfection was performed according to the manufacturer's instruction in Qiagen TransMessenger kit and as we described previously [7]. 


\section{Preparation of purified SR from bovine coronary arterial smooth muscle}

Fresh bovine hearts were obtained from a local abattoir, and the coronary arteries were rapidly dissected, and SR-enriched microsomes (SR membrane) of these arteries were prepared as we described previously $[3,10,11]$. Briefly, the dissected coronary arteries (outer diameter 500$1,000 \mu \mathrm{m})$ were cleared of surrounding fat and connective tissues. The arteries were cut open along the longitudinal axis and pinned lumen side up to a Sylgard-coated dish containing icecold HEPES buffered physiological saline solution (in mM: $140 \mathrm{NaCl}, 4.7 \mathrm{KCl}, 1.6 \mathrm{CaCl}_{2}$, $1.17 \mathrm{MgSO} 4,1.18 \mathrm{NaH}_{2} \mathrm{PO} 4,5.5$ glucose, and 10 HEPES, pH 7.4). A sharp blade was used to scratch endothelial cells from the arteries. Then the segments of the arteries were cut into small (2- to 3-mm-long) pieces and homogenized with a Polytron (Brinkman) in ice-cold MOPS buffer ( $0.9 \% \mathrm{NaCl}, 10 \mathrm{mM}$ MOPS (pH 7.0), $2 \mathrm{M}$ leupeptin, and $0.8 \mathrm{M}$ benzamidine). The homogenate was centrifuged at $4,000 \mathrm{~g}$ for $20 \mathrm{~min}$ at $4{ }^{\circ} \mathrm{C}$, and the supernatant was further centrifuged at $8,000 \mathrm{~g}$ for $20 \mathrm{~min}$ at $4^{\circ} \mathrm{C}$ and then at $40,000 \mathrm{~g}$ for $30 \mathrm{~min}$. The pellet, termed the crude SR membrane, was resuspended in the SR solution $(0.9 \% \mathrm{NaCl}, 0.3 \mathrm{M}$ sucrose, and $0.1 \mathrm{M}$ phenylmethylsulfonyl fluoride) [10]. The crude SR was further fractionated on a discontinuous sucrose gradient $[3,19,20]$. The following sucrose solutions (percent by weight) containing $10 \mathrm{mM}$ HEPES, pH 7.0, were layered sequentially in a centrifuge tube (model SW28, Beckman) as follows: $4 \mathrm{ml}$ of $45 \%, 7 \mathrm{ml}$ of $40 \%, 12 \mathrm{ml}$ of $35 \%, 7 \mathrm{ml}$ of $30 \%$, and 4 $\mathrm{ml}$ of $27 \%$. Crude SR (30 mg) was layered on top of the gradient, and the tube was spun at $64,000 \mathrm{~g}$ overnight. A fraction from $37-40 \%$ sucrose contained the purified SR, which was collected and diluted in MOPS buffer [0.9\% $\mathrm{NaCl}, 10 \mathrm{mM}$ MOPS (pH 7.0), $2 \mu \mathrm{M}$ leupeptin, and $0.8 \mu \mathrm{M}$ benzamidine] and subjected to further centrifugation at $40,000 \mathrm{~g}$ for $90 \mathrm{~min}$ at $4^{\circ}$ C. The pellet was resuspended in the SR solution, aliquoted, frozen in liquid N2, and stored at $80^{\circ} \mathrm{C}$.

\section{ESR Detection of $\mathrm{O}_{2}{ }^{-}$}

Purified SR from bovine coronary artery was suspended in modified Kreb's_HEPEs buffer containing deferoximine $(100 \mu \mathrm{M})[7,21]$. The NOX activity to produce $\mathrm{O}_{2}{ }^{--}$in the SR was examined by addition of $1 \mathrm{mM}$ NADH as a substrate in the $100 \mu \mathrm{g}$ purified SR mixture and incubated for $15 \mathrm{~min}$, and then supplied with $1 \mathrm{mM} \mathrm{O}_{2}{ }^{--}$- specific spin trap 1-hydroxy-3methoxycarbonyl-2,2,5,5-tetramethylpyrrolidine $(\mathrm{CMH})$ in the presence or absence of NOX inhibitors apocynin (Apo, $100 \mu \mathrm{M})$ or SOD $(200 \mathrm{U} / \mathrm{ml})$ or its mimetic Tiron $(1 \mathrm{mM})$. The SR mixture loaded in glass capillaries was immediately analyzed for $\mathrm{O}_{2}{ }^{-}$production kinetically for $10 \mathrm{~min}$. The ESR settings were as follows: biofield, 3350; field sweep, $60 \mathrm{G}$; microwave frequency, $9.78 \mathrm{GHz}$; microwave power, $20 \mathrm{~mW}$; modulation amplitude, $3 \mathrm{G}$; 4,096 points of resolution; receiver gain, 500; and kinetic time, $10 \mathrm{~min}$.

\section{Statistics}

Data are expressed as means \pm SE. The significance of the differences in mean values between and within multiple groups such as multiple time points was examined by ANOVA for repeated measures followed by Duncan's multiple range test. Student's $t$-test was used to evaluate the statistical significance of differences between two paired observations. $P<0.05$ was considered statistically significant.

\section{RESULTS}

\section{Localized ROS production by the SR in response to Oxo}

Using confocal microscopic analysis, we dynamically monitored the cytosolic $\mathrm{H}_{2} \mathrm{O}_{2}$ level by measuring oxidized- $\mathrm{H}_{2}$ DCFDA green fluorescence and at the same time we also recorded SR staining by ER-Tracker red dye. Figure 1A shows typical sequential fluorescent images when a CAM received Oxo at $80 \mu \mathrm{M}$. It was found that green fluorescence intensity of $\mathrm{H}_{2}$ DCFDA 
markedly increased in a time-dependent manner, but the red fluorescence staining of the SR remains unchanged. The merged images showed a number of yellow spots, which also increased in a time-dependent manner. These spots represent colocalization of $\mathrm{O}_{2}{ }^{-}{ }^{-}$with the $\mathrm{SR}$, and increased intensity indicated ROS derived from the SR. In addition to yellow areas in the merged images, rest areas of green fluorescence represent non-SR-derived ROS or global ROS levels. To quantitate SR-derived ROS and global or non-SR ROS, we used the ImagePro Plus version 6.0 software to analyze the yellow spot intensity as well as green staining intensity from the merged image based on the color spectra. Figure 1B summarized the results. The normalized yellow fluorescence intensity significantly increased by more than 4 folds when CAMs were exposed to Oxo over the $12 \mathrm{~min}$. The global ROS levels as shown by green staining also increased with a less intensity than local ROS around the SR.

\section{Effects of NOX inhibitors and Nox4 siRNA on SR-derived ROS production}

To demonstrate that ROS derived from the SR are due to $\mathrm{O}_{2}{ }^{-}$production by activation of SR NOX, we tested the effects of SOD combined with catalase and NOX inhibition or downregulation on local ROS levels. First, cell permeable polyethylene-glycol (PEG)conjugated $\mathrm{O}_{2} \cdot{ }^{-}$dismutase (PEG-SOD) [17] and polyethylene-glycol (PEG)-conjugated catalase (PEG-Catalase) [18] were used in combination when CAMs were stimulated by Oxo. It was found that SOD and Catalase significantly blocked ROS increase colocalized with the SR (Figure 2B).

Then, we tested whether NOX is involved in local ROS production using its inhibitors, DPI and Nox 4 siRNA. The successful inhibitory effects of Nox4 siRNA on the expression of this Nox isoform was confirmed by the Western blot analysis in CAMs (anti-Nox4 antibody, Santa Cruz); It was shown that the expression of Nox 4 was almost completely disrupted by its siRNA, as shown in Fig. 2A. The results from these experiments were also summarized in Figure 2B, showing that NOX inhibition or gene silencing almost completely abolished the SR-derived ROS production.

In addition to the use of Oxo as agonist, we also tested the effects of the NOX inhibition or gene silencing on ROS production induced by another stimulator of NOX in CAMs, namely, $\mathrm{Ca}^{2+}$ ionophere, A23187 [22]. It was found that A23187 $(1 \mu \mathrm{M})$ markedly increased local ROS production in CAMs. When these cells were pretreated with PEG-SOD and PEG-catalase in combination, this A23187-induced local ROS production was substantially attenuated.

Similarly, inhibition of NOX activity by DPI or silencing its expression by Nox4 siRNA also significantly blocked this local ROS production induced by A23187 (Fig 2C).

\section{Effect of cADPR-RyR-Ca ${ }^{2+}$ signaling pathway inhibitors on local $\mathrm{O}_{2} \cdot{ }^{-}$production from the SR \\ Given the $\mathrm{Ca}^{2+}$ sensitivity of NOX activity, we determined whether cADPR-RyR-Ca ${ }^{2+}$ signaling pathway contributes to the activation of local ROS production via NOX on the SR. It was found that ADP-ribosyl cyclase inhibition by nicotinamide (Nicot.), cADPR antagonist, 8-Br-cADPR, or RyR-Ca ${ }^{2+}$ release channel blockade by ryanodine at a large dose (Rya), Oxo- induced $\mathrm{O}_{2}{ }^{-}$production significantly decreased by 3.03, 2.92 and 3.17 folds, respectively, compared to Oxo alone. These results were summarized in Figure 3. It was also found that 2- aminoethoxydiphenyl borate $(2-\mathrm{APB} ; 50 \mu \mathrm{M})$, the inhibitor of $\operatorname{Ins}(1,4,5) \mathrm{P}_{3}$ receptor, had no effects on the Oxo-induced $\mathrm{O}_{2}{ }^{-}$production from the $\mathrm{SR}$.}

\section{Effects of CADPR-RyR/Ca ${ }^{2+}$ pathway RNA interference on SR-derived $\mathrm{O}_{2}{ }^{--}$production}

To further address the regulatory role of cADPR-RyR/Ca ${ }^{2+}$ signaling pathway in SR production of $\mathrm{O}_{2}{ }^{-}$, we examined the effects of RNA interference of two genes coding ADPribosyl cyclase and RyR-2. In these experiments, CAMs were pretreated with siRNA of ADPribosyl cyclase or RyR receptor and satisfied interference efficiency of siRNA had been 
confirmed by real time RT-PCR of their corresponding mRNA and Western blot analysis of their proteins (data not shown). Under confocal fluorescence microscope, the intensity of yellow stains produced by green $\mathrm{H}_{2} \mathrm{O}_{2}$ dye was significantly reduced in either ADP-ribosyl cyclase or RyR receptor siRNA-treated CAMs. Normalized fluorescence intensity of this colocalization before and after siRNA treatment was presented in Figure 4.

\section{$\mathrm{Ca}^{2+}$ regulation of $\mathrm{NAD}(\mathrm{P}) \mathrm{H}$ oxidase-derived $\mathrm{O}_{2}{ }^{--}$production from purified $\mathrm{SR}$ analyzed by ESR}

Using ESR spectrometric assay, we demonstrated that $\mathrm{NAD}(\mathrm{P}) \mathrm{H}$ oxidase was functioning in the purified $\mathrm{SR}$ from bovine CAMs. $\mathrm{NAD}(\mathrm{P}) \mathrm{H}$-dependent $\mathrm{O}_{2}{ }^{-}$production was measured using NADH as substrate. NADH was chosen as the substrate because of the preference of SR Nox4containing NAD(P)H oxidase for NADH [23,24], rather than NADPH. Figure 5A shows representative ESR spectrographs of $\mathrm{O}_{2}{ }^{-}$trapped by 1-hydroxy-3-methoxycarbonyl-2,2,5,5tetramethylpyrrolidine $(\mathrm{CMH})$ in the reaction mixture with $1 \mathrm{mM} \mathrm{NADH}$. As summarized in Figure $5 \mathrm{~B}, \mathrm{O}_{2}{ }^{--}$production in these purified SR was significantly increased by 1.7 folds over a 16-min reaction compared to control. A rapid increase in $\mathrm{O}_{2}{ }^{-}$production was observed at the first $5 \mathrm{~min}$ of the reaction. This SR-derived $\mathrm{O}_{2}{ }^{-}$production was almost blocked by NAD (P)H oxidase inhibitors Apo $(100 \mu \mathrm{M})$, SOD $(200 \mathrm{U} / \mathrm{ml})$, and its mimetic Tiron $(1 \mathrm{mM})$ (Figure 6). To determine the $\mathrm{Ca}^{2+}$ sensitivity of this SR enzyme, we examined the effects of different $\mathrm{Ca}^{2+}$ concentrations on $\mathrm{SR}_{2}{ }^{--}$production. The results are presented in Figure 6. In the presence of $1 \mathrm{mM} \mathrm{NADH}, \mathrm{Ca}^{2+}$ increases in the reaction mixtures produced a concentrationdependent enhancement of $\mathrm{O}_{2}{ }^{-}$production as measured by ESR trapping. A 1.5 fold increase was reached at $1 \mu \mathrm{M}$ of $\mathrm{Ca}^{2+}$ in the reaction.

\section{DISCUSSION}

There is increasing evidence that $\mathrm{NAD}(\mathrm{P}) \mathrm{H}$ oxidase is a major source of $\mathrm{O}_{2}{ }^{-}$in the vasculature and that $\mathrm{O}_{2}{ }^{-}$from this enzyme serves as an important physiological redox signaling molecule to participate in the regulation of vascular function [1,25-28]. In vascular smooth muscle cells (VSMCs), recent studies have reported that there are membrane-bound and intracellular nonmitochondrial $\mathrm{NAD}(\mathrm{P}) \mathrm{H}$ oxidases, which are all capable of producing $\mathrm{O}_{2}{ }^{-}$and contributing to intracellular $\mathrm{O}_{2}{ }^{-}$concentrations in these cells $[1,29]$. However, it remains unknown how the intracellular $\mathrm{O}_{2} .^{-}$concentrations are determined by this NAD(P)H oxidase in VSMCs. Although a membrane - bound $\mathrm{NAD}(\mathrm{P}) \mathrm{H}$ oxidase is assumed to produce $\mathrm{O}_{2}{ }^{-}$toward the inside of these cells [1], the topology of $\mathrm{NAD}(\mathrm{P}) \mathrm{H}$ oxidase subunits indicates that membraneassociated NAD(P)H oxidase should not release $\mathrm{O}_{2} \cdot{ }^{-}$into cytosol. More recent studies on subcellular localization of vascular $\mathrm{NAD}(\mathrm{P}) \mathrm{H}$ oxidase subunits also demonstrated that $\mathrm{O}_{2}{ }^{-{ }^{-}}$ within VSMCs may not be derived from plasma membrane NAD(P)H oxidase [5,24], but rather from intracellular compartmental $\mathrm{NAD}(\mathrm{P}) \mathrm{H}$ oxidase [3,6]. Although there are reports about the localization of $\mathrm{NAD}(\mathrm{P}) \mathrm{H}$ oxidases in different cellular organelles such as mitochondria, SR and Golgi apparatus, little is known how $\mathrm{O}_{2}{ }^{-}$production in these intracellular compartments are activated or regulated in VSMCs.

In the present study, we characterized an $\mathrm{NAD}(\mathrm{P}) \mathrm{H}$ oxidase-dependent $\mathrm{O}_{2}{ }^{-}$production from the SR in intact CAMs and explored the regulatory mechanisms associated with a novel $\mathrm{Ca}^{2+}$ signaling pathway, namely, the role of cADPR-mediated $\mathrm{Ca}^{2+}$ mobilization mechanism. In these experiments, we used $\mathrm{M}_{1}$ agonist, oxotremorine (Oxo), to stimulate $\mathrm{O}_{2}{ }^{-}$production via $\mathrm{NAD}(\mathrm{P}) \mathrm{H}$ oxidase in CAMs. The reason for the use of this $\mathrm{M}_{1}$ agonist, Oxo, is due to its strong action inducing $\mathrm{O}_{2}{ }^{-}$production and vasoconstriction in denuded bovine coronary arteries $[7,30]$. In particular, previous studies have shown that bovine coronary arteries are insensitive to classical vasoconstrictors such as angiotensin II, norepinephrine, and vasopressin [7,31-33] and therefore the vasoconstrictor action of this $\mathrm{M}_{1}$ agonist is unique in studying the 
mechanism of bovine coronary vasoconstriction. This compound-induced vasoconstriction was often found to be accompanied by $\mathrm{O}_{2}{ }^{-}$production, and the latter may further enhance or amplify the vasoconstriction in these arteries [3,30,34]. In addition, many studies have demonstrated that $\mathrm{M}_{1}$ receptor activation produces vasoconstriction primarily through cADPR$\mathrm{RyR} \mathrm{Ca}^{2+}$ signaling pathway in coronary arteries $[13,35]$. Based on these findings, it is proposed that $\mathrm{M}_{1}$ agonist is a unique tool compound for studies of $\mathrm{Ca}^{2+}$ and redox signaling and their interactions in CAMs $[30,36]$.

Using Confocal microscopy, we first detected $\mathrm{O}_{2}{ }^{-}$production in the SR of intact CAMs. In these experiments, CAMs were treated by Oxo, and $\mathrm{O}_{2} \cdot{ }^{-}$production in the SR were measured by co-staining of CM- $\mathrm{H}_{2}$ DCFDA (green) for $\mathrm{H}_{2} \mathrm{O}_{2}$ and ER-Tracker (red) for the SR. CM$\mathrm{H}_{2}$ DCFDA was used as a general indicator of intracellular ROS formation, primarily derived from $\mathrm{O}_{2} \cdot{ }^{-}$production. Although dihydroethidium (DHE) was widely used to directly measure intracellular $\mathrm{O}_{2}{ }^{-}$production, which is based on that DHE is converted to ethidium bromide (EB) upon oxidation by superoxide, and these oxidized EB translocated to the nucleous where it intercalates with DNA to generate red fluorescence. It is obvious that the site of accumulation of bright-red fluorescence from oxidized DHE and DNA complex is not a suitable indicator of the location where ROS were produced [37]. In contrast, $\mathrm{CM}-\mathrm{H}_{2}$ DCFDA is able to localize cellular production of ROS within the tissue, and the sensitivity to detect ROS within a single cell, these strengths has made $\mathrm{CM}-\mathrm{H}_{2} \mathrm{DCFDA}$ widely used in the measurement of intracellular localized ROS by imaging assay $[38,39]$. With the help of an Image-Pro Plus analysis software (version 6.0), the intensity of spots with different colors or spectra could be quantified in overlaid fluorescent confocal images. By measuring the intensity of yellow spots formed by overlay of CM- $\mathrm{H}_{2}$ DCFDA green fluorescence and SR-tracker red fluorescence, the level of $\mathrm{H}_{2} \mathrm{O}_{2}$ primarily derived from the SR could be detected. By analysis of green fluorescence intensity, total $\mathrm{H}_{2} \mathrm{O}_{2}$ or $\mathrm{H}_{2} \mathrm{O}_{2}$ from other cellular resources was assessed. It was found that Oxo time-dependently increased $\mathrm{H}_{2} \mathrm{O}_{2}$ production around the $\mathrm{SR}$, as measured by yellow fluorescent intensity. Although this $\mathrm{M}_{1}$-agonist also increased global ROS production, as measured by green fluorescence intensity, the increase in SR-derived ROS was more significantly intensive. In the presence of cell permeable of PEG-SOD and PEG-catalase, Oxoinduced SR production of ROS was substantially blocked. These results suggest that this confocal microscopic local assay does detect $\mathrm{O}_{2}{ }^{-}$production from the SR of intact CAMs. Although $\mathrm{O}_{2}{ }^{-}$or other ROS production was reported in different cellular compartments [3, 40], many of previous studies used isolated organelles such as mitochondria and SR to analyze related ROS or enzyme activity [3,40]. The confocal microscopic analysis of local production of ROS has been reported only in studies of mitochondrial redox status or ROS release from this organelles in intact cells $[39,41,42]$. In those studies, $\mathrm{CM}-\mathrm{H}_{2}$ DCFDA was also used to localize ROS derived from the mitochondria with the help of quantitative analysis of its localization with mitochondrial markers. To our knowledge, the present study represents the first report to use such technique to detect ROS derived from the SR of intact CAMs.

It is well known that several potential enzymatic sources of $\mathrm{O}_{2} \cdot{ }^{-}$in the cardiovascular system, such as xanthine oxidase, mitochondrial respiratory chain, arachidonic acid metabolizing system, uncoupled NO synthase, and NAD(P)H oxidase [43,44] may contribute to the production of $\mathrm{O}_{2}{ }^{-}$or ROS within different cells. However, accumulating evidence has indicated that non-mitochondrial $\mathrm{NAD}(\mathrm{P}) \mathrm{H}$ oxidase may be a major resource for intracellular ROS in vascular smooth muscle cells and thereby this enzyme system play an important role in the regulation of vascular smooth muscle function under physiological and pathological conditions [1,25-28]. In this regard, previous studies have reported that Nox4 is a major catalytic subunit of $\mathrm{NAD}(\mathrm{P}) \mathrm{H}$ oxidase in different organelle of vascular smooth muscle cells including the SR $[3,7,24]$. In the present study, we tested whether this $\mathrm{NAD}(\mathrm{P}) \mathrm{H}$ oxidase contributes to the ROS production from the SR. We performed confocal analysis of SR-derived ROS production in CAMs in the absence or presence of a specific inhibitor DPI of this enzyme 
or Nox4 siRNA. It was demonstrated that ROS production from the SR was markedly reduced when NAD(P)H oxidase was inhibited or a Nox4 siRNA was introduced, no matter whether Oxo or A23187 was used as stimuli. These results suggest that NAD(P)H oxidase is primarily responsible for the production of ROS from the SR. In previous studies using isolated SR, the expression and activity of an $\mathrm{NAD}(\mathrm{P}) \mathrm{H}$ oxidase were also detected in cardiomycytes and smooth muscle cells $[3,45]$. Our present results further support the view that this NAD(P)H oxidase is functioning even when vascular smooth muscle produces vasomotor response to physiological stimuli.

Another important question being addressed in the present study is whether the activity of NAD (P)H oxidase on the SR is regulated by its $\mathrm{Ca}^{2+}$ signaling mechanisms. Since NAD(P)H oxidase has been reported to be a $\mathrm{Ca}^{2+}$-dependent enzyme for $\mathrm{O}_{2} \cdot{ }^{-}$production, it is possible that a local $\mathrm{Ca}^{2+}$ regulatory mechanism may control its activity. To test this hypothesis, we performed a series experiments to examine the possible pathway that may be involved in the regulation of $\mathrm{NAD}(\mathrm{P}) \mathrm{H}$ oxidase activity. First, we tested whether $\mathrm{IP}_{3}$ or ryanodine-sensitive $\mathrm{Ca}^{2+}$ mobilizing pathway has impact on the $\mathrm{NAD}(\mathrm{P}) \mathrm{H}$ oxidase activity. It was found that RyR inhibition rather than $\mathrm{IP}_{3}$ antagonist blocked Oxo-induced activation of SR NAD(P)H oxidase. Further experiments using RyR2 siRNA also demonstrated that Oxo-induced NAD(P)H oxidase activity was abolished. It seems that $\mathrm{NAD}(\mathrm{P}) \mathrm{H}$ oxidase activity is dependent on RyR activation by Oxo, rather than $\mathrm{IP}_{3} \mathrm{R}$ activation. Indeed, previous studies confirmed that Oxo-induced vasoconstrictor response primarily through RyR-mediated $\mathrm{Ca}^{2+}$ mobilization from the SR $[13,14]$. Second, we tested the role of an $\mathrm{IP}_{3}$-independent $\mathrm{Ca}^{2+}$ releasing mechanism, cADPR pathway, in the regulation of SR NAD(P)H oxidase. This cADPR-mediated $\mathrm{Ca}^{2+}$ has been also proposed as a major $\mathrm{Ca}^{2+}$ mobilizing or vasomotor response during $\mathrm{M}_{1}$ receptor activation $[13,14]$. Interestingly, we found that all manipulations of this signaling pathway could block Oxo-induced ROS production from the SR, no matter whether cADPR-producing enzyme was inhibited or its gene silenced, or cADPR antagonist was used. Given that cADPR produces $\mathrm{Ca}^{2+}$ mobilization from the SR mainly through RyR activation, these results suggest that NAD (P)H oxidase activity on the SR is associated with cADPR-mediated activation of RyR. It may be proposed that $\mathrm{M}_{1}$ receptor stimulation by Oxo leads to cADPR production and the latter induces $\mathrm{Ca}^{2+}$ releasing and thereby results in local activation of NAD(P)H oxidase on the SR.

Finally, we directly tested the $\mathrm{Ca}^{2+}$ sensitivity of NAD(P)H oxidase on the SR isolated from CAMs. Using ESR spectrometry, $\mathrm{O}_{2}{ }^{-}$production was analyzed by incubation of the SR with $\mathrm{NAD}(\mathrm{P}) \mathrm{H}$ oxidase substrate, $\mathrm{NADH}$. After validation of this ESR detection for $\mathrm{O}_{2}{ }^{-}$production by $\mathrm{NAD}(\mathrm{P}) \mathrm{H}$ oxidase using $\mathrm{O}_{2}{ }^{-}{ }^{-}$scavengers or different $\mathrm{NAD}(\mathrm{P}) \mathrm{H}$ oxidase inhibitors, we tested whether the SR NAD(P)H oxidase activity is altered by increasing $\mathrm{Ca}^{2+}$ concentrations in the reaction mixtures. Consistent with the results reported in other membrane fractions [3, 22,46], increases in $\mathrm{Ca}^{2+}$ significantly enhanced the activity of $\mathrm{NAD}(\mathrm{P}) \mathrm{H}$ oxidase from the SR. It is obvious that these results provide direct evidence that elevated intracellular $\mathrm{Ca}^{2+}$ can be an critical activator of $\mathrm{NAD}(\mathrm{P}) \mathrm{H}$ oxidase, which regulates local generation of $\mathrm{O}_{2}{ }^{-}$from the SR. Given the sensitivity of RyR to ROS, this $\mathrm{Ca}^{2+}$ activation of NAD(P)H oxidase may constitute an amplification system between $\mathrm{Ca}^{2+}$ and redox signaling in CAMs. In this way, $\mathrm{Ca}^{2+}$ enhances NAD(P)H oxidase activity to produce $\mathrm{O}_{2}{ }^{--}$, and ROS sensitizes RyRs to release more $\mathrm{Ca}^{2+}$, forming a local feedforward regulatory circuit.

In summary, the present study demonstrated that 1) $\mathrm{O}_{2} \cdot{ }^{-}$was locally derived from SR in response to $\mathrm{M}_{1}$ agonist in CAMs; 2) SR-derived $\mathrm{O}_{2}{ }^{-}$production was blocked by $\mathrm{NAD}(\mathrm{P}) \mathrm{H}$ oxidase inhibitor and Nox4 siRNA; 3) SR-derived $\mathrm{O}_{2} \cdot{ }^{-}$production was abolished by the inhibitors of ADP-ribosyl cyclase, RyR, and cADPR antagonist but not by $\mathrm{IP}_{3}$ antagonist; 4) both ADP-ribosyl cyclase and RyR siRNA inhibited $\mathrm{O}_{2}{ }^{-}$production from SR; and 5) Purified SR produced $\mathrm{O}_{2}{ }^{-}$was dependent on $\mathrm{NAD}(\mathrm{P}) \mathrm{H}$ oxidase in a $\mathrm{Ca}^{2+}$ sensitive manner. As shown in a schematic diagram in Figure 7, we conclude that $\mathrm{NAD}(\mathrm{P}) \mathrm{H}$ oxidase on the SR of intact 
CAMs is functioning in response to physiological stimuli such as $\mathrm{M}_{1}$ receptor activation and that this local enzyme is sensitive to intracellular $\mathrm{Ca}^{2+}$ regulation associated with cADPR-RyR signaling pathway. Given previous evidence of high sensitivity of RyRs to redox changes, increased $\mathrm{O}_{2}{ }^{-}$production may enhance the activity of these receptors releasing more $\mathrm{Ca}^{2+}$. The latter again activates NAD(P)H oxidase on the SR constituting a feed forward mechanism. This interaction of $\mathrm{Ca}^{2+}$ and redox signaling around the SR may importantly contribute to $\mathrm{Ca}^{2+}$ regulation of coronary arterial smooth muscle and thereby enhance vasoconstrictor responses.

\section{Acknowledgements}

This study was supported by grants HL057244, HL075316 and DK054927 from National Institutes of Health.

\section{References}

1. Griendling KK, Sorescu D, Ushio-Fukai M. Circ Res 2000;86(5):494-501. [PubMed: 10720409]

2. Mohazzab KM, Kaminski PM, Wolin MS. Am J Physiol 1994;266(6 Pt 2):H2568-2572. [PubMed: 8024019]

3. Yi XY, Li VX, Zhang F, Yi F, Matson DR, Jiang MT, Li PL. Am J Physiol Heart Circ Physiol 2006;290 (3):H1136-1144. [PubMed: 16227345]

4. Patterson C, Ruef J, Madamanchi NR, Barry-Lane P, Hu Z, Horaist C, Ballinger CA, Brasier AR, Bode C, Runge MS. J Biol Chem 1999;274(28):19814-19822. [PubMed: 10391925]

5. Brandes RP, Kreuzer J. Cardiovasc Res 2005;65(1):16-27. [PubMed: 15621030]

6. Wolin MS, Ahmad M, Gupte SA. Am J Physiol Lung Cell Mol Physiol 2005;289(2):L159-173. [PubMed: 16002998]

7. Zhang G, Zhang F, Muh R, Yi F, Chalupsky K, Cai H, Li PL. Am J Physiol Heart Circ Physiol 2007;292 (1):H483-495. [PubMed: 16963617]

8. Lee HC, Aarhus R, Graeff R, Gurnack ME, Walseth TF. Nature 1994;370(6487):307-309. [PubMed: 8035880]

9. Lee HC, Aarhus R, Graeff RM. J Biol Chem 1995;270(16):9060-9066. [PubMed: 7721819]

10. Li PL, Tang WX, Valdivia HH, Zou AP, Campbell WB. Am J Physiol Heart Circ Physiol 2001;280 (1):H208-215. [PubMed: 11123235]

11. Tang WX, Chen YF, Zou AP, Campbell WB, Li PL. Am J Physiol Heart Circ Physiol 2002;282 (4):H1304-1310. [PubMed: 11893565]

12. Geiger J, Zou AP, Campbell WB, Li PL. Hypertension 2000;35(1 Pt 2):397-402. [PubMed: 10642331]

13. Ge ZD, Zhang DX, Chen YF, Yi FX, Zou AP, Campbell WB, Li PL. J Vasc Res 2003;40(1):28-36. [PubMed: 12644723]

14. Zhang F, Zhang G, Zhang AY, Koeberl MJ, Wallander E, Li PL. Am J Physiol Heart Circ Physiol 2006;291(1):H274-282. [PubMed: 16473958]

15. Li PL, Chen CL, Bortell R, Campbell WB. Circ Res 1999;85(4):349-356. [PubMed: 10455063]

16. Li PL, Zou AP, Campbell WB. Am J Physiol 1998;275(3 Pt 2):H1002-1010. [PubMed: 9724306]

17. Landmesser U, Cai H, Dikalov S, McCann L, Hwang J, Jo H, Holland SM, Harrison DG. Hypertension 2002;40(4):511-515. [PubMed: 12364355]

18. Defoort EN, Kim PM, Winn LM. Mol Pharmacol 2006;69(4):1304-1310. [PubMed: 16377765]

19. Salama G, Abramson J. J Biol Chem 1984;259(21):13363-13369. [PubMed: 6208194]

20. Xia R, Webb JA, Gnall LL, Cutler K, Abramson JJ. Am J Physiol Cell Physiol 2003;285(1):C215221. [PubMed: 12646413]

21. Chalupsky K, Cai H. Proc Natl Acad Sci U S A 2005;102(25):9056-9061. [PubMed: 15941833]

22. Smith RJ, Iden SS. Inflammation 1981;5(3):177-192. [PubMed: 6271675]

23. Kobayashi T, Zinchuk VS, Okada T, Wakiguchi H, Kurashige T, Takatsuji H, Seguchi H. Histochem Cell Biol 2000;113(4):251-257. [PubMed: 10857476] 
24. Lassegue B, Clempus RE. Am J Physiol Regul Integr Comp Physiol 2003;285(2):R277-297. [PubMed: 12855411]

25. Mohazzab KM, Wolin MS. Am J Physiol 1994;267(6 Pt 1):L815-822. [PubMed: 7810685]

26. Rajagopalan S, Kurz S, Munzel T, Tarpey M, Freeman BA, Griendling KK, Harrison DG. J Clin Invest 1996;97(8):1916-1923. [PubMed: 8621776]

27. Suzuki YJ, Ford GD. J Mol Cell Cardiol 1999;31(2):345-353. [PubMed: 10093047]

28. Zulueta JJ, Yu FS, Hertig IA, Thannickal VJ, Hassoun PM. Am J Respir Cell Mol Biol 1995;12(1): 41-49. [PubMed: 7529030]

29. Cai H. Circ Res 2005;96(8):818-822. [PubMed: 15860762]

30. Zhang AY, Yi F, Teggatz EG, Zou AP, Li PL. Microvasc Res 2004;67(2):159-167. [PubMed: 15020207]

31. Zhang AY, Yi F, Zhang G, Gulbins E, Li PL. Hypertension 2006;47(1):74-80. [PubMed: 16344372]

32. Zhang DX, Yi FX, Zou AP, Li PL. Am J Physiol Heart Circ Physiol 2002;283(5):H1785-1794. [PubMed: 12384455]

33. Li PL, Jin MW, Campbell WB. Hypertension 1998;31(1 Pt 2):303-308. [PubMed: 9453320]

34. Wilson HL, Dipp M, Thomas JM, Lad C, Galione A, Evans AM. J Biol Chem 2001;276(14):1118011188. [PubMed: 11116136]

35. Higashida H, Yokoyama S, Hashii M, Taketo M, Higashida M, Takayasu T, Ohshima T, Takasawa S, Okamoto H, Noda M. J Biol Chem 1997;272(50):31272-31277. [PubMed: 9395453]

36. Zhang AY, Li PL. J Cell Mol Med 2006;10(2):407-422. [PubMed: 16796808]

37. Yeung T, Touret N, Grinstein S. Curr Opin Microbiol 2005;8(3):350-358. [PubMed: 15939361]

38. Dikalov S, Griendling KK, Harrison DG. Hypertension 2007;49(4):717-727. [PubMed: 17296874]

39. Zmijewski JW, Moellering DR, Le Goffe C, Landar A, Ramachandran A, Darley-Usmar VM. Am J Physiol Heart Circ Physiol 2005;289(2):H852-861. [PubMed: 15805232]

40. Liu Y, Zhao H, Li H, Kalyanaraman B, Nicolosi AC, Gutterman DD. Circ Res 2003;93(6):573-580. [PubMed: 12919951]

41. Lecour S, Van der Merwe E, Opie LH, Sack MN. J Cardiovasc Pharmacol 2006;47(1):158-163. [PubMed: 16424801]

42. Jou MJ, Peng TI, Wu HY, Wei YH. Ann N Y Acad Sci 2005;1042:221-228. [PubMed: 15965066]

43. Wolin MS. Microcirculation 1996;3(1):1-17. [PubMed: 8846267]

44. Wolin MS, Ahmad M, Gupte SA. Kidney Int 2005;67(5):1659-1661. [PubMed: 15840006]

45. Hidalgo C, Aracena P, Sanchez G, Donoso P. Biol Res 2002;35(2):183-193. [PubMed: 12415735]

46. Carriedo SG, Yin HZ, Sensi SL, Weiss JH. J Neurosci 1998;18(19):7727-7738. [PubMed: 9742143] 
A

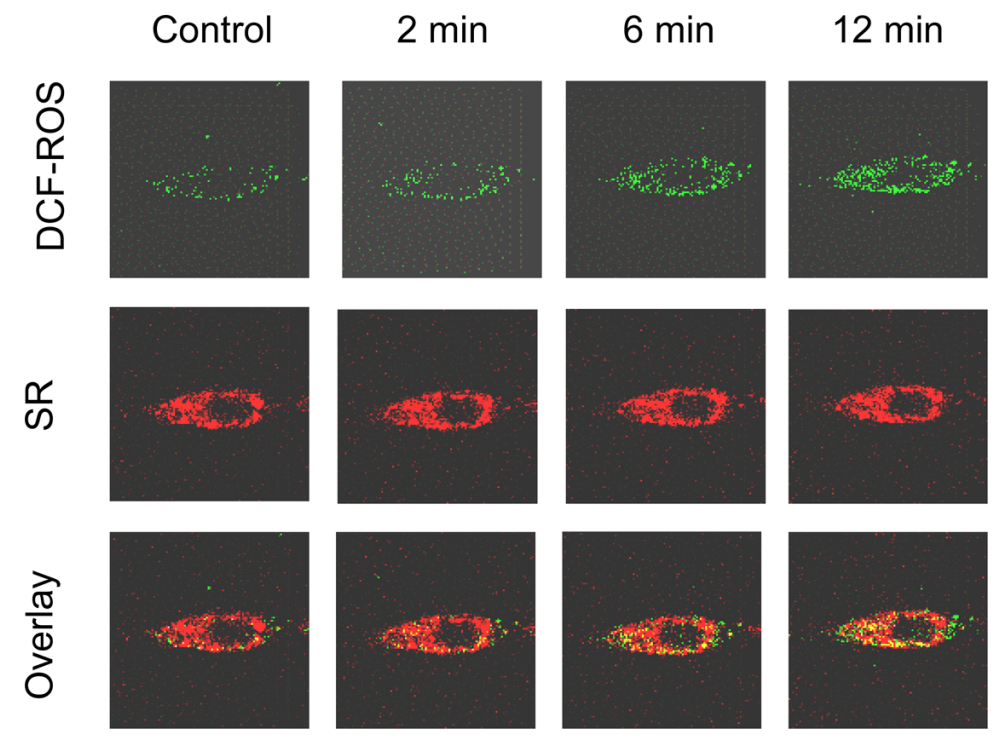

B

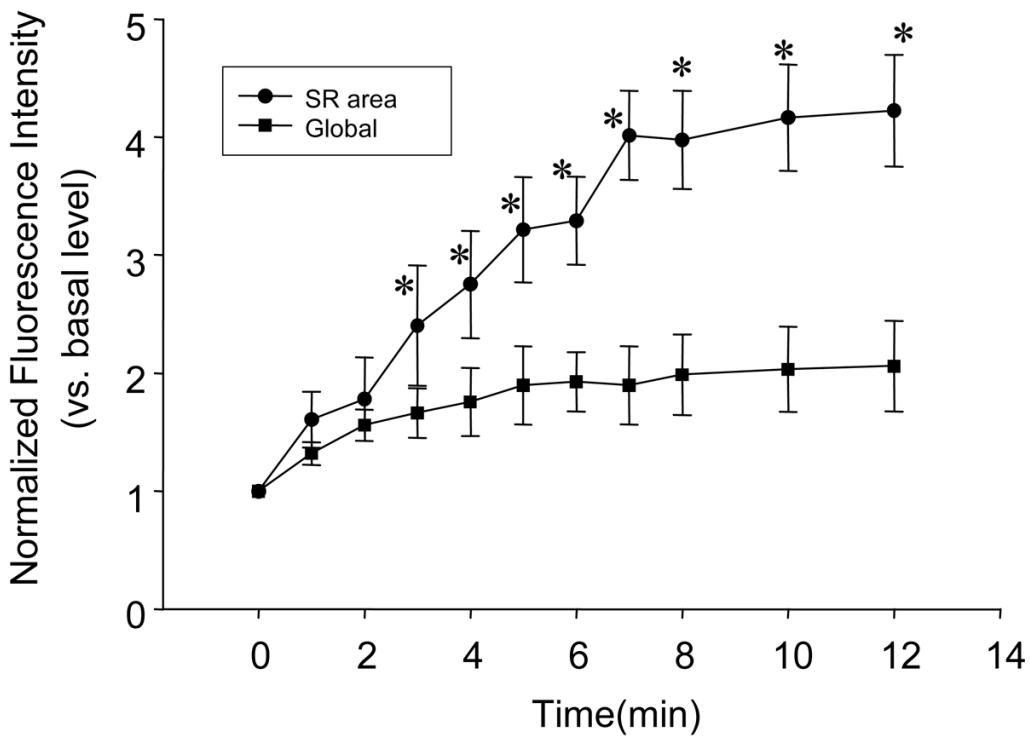

Fig. 1.

Time-dependent local superoxide $\left(\mathrm{O}_{2} \cdot{ }^{-}\right)$production from sarcoplasmic reticulum (SR) in intact coronary arterial myocytes (CAMs) by confocal fluorescence microscopy under the treatment of $80 \mu \mathrm{M}$ oxotremorine (Oxo). CAMs were loaded with ER-Tracker ${ }^{\mathrm{TM}}$ dyes for the trace of SR (red) and CM- $\mathrm{H}_{2}$ DCFDA (DCF) for $\mathrm{H}_{2} \mathrm{O}_{2}$ detection as ROS indicator (green). A: Typical cell images with green fluorescence for ROS detection and red fluorescence for SR staining. The merged images with yellow spots or staining show colocalization of ROS derived from the SR. B: Summarized digitized data dissecting SR-derived ROS level (yellow in images) from global ROS or non-SR ROS (green in images). $\mathrm{n}=6, * \mathrm{P}<0.05$ compared with basal level. 
A

Control Scramble siRNA-Nox4

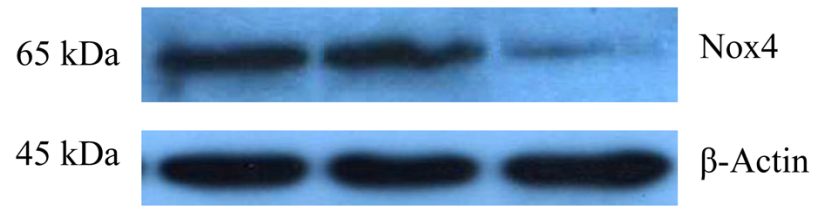

B

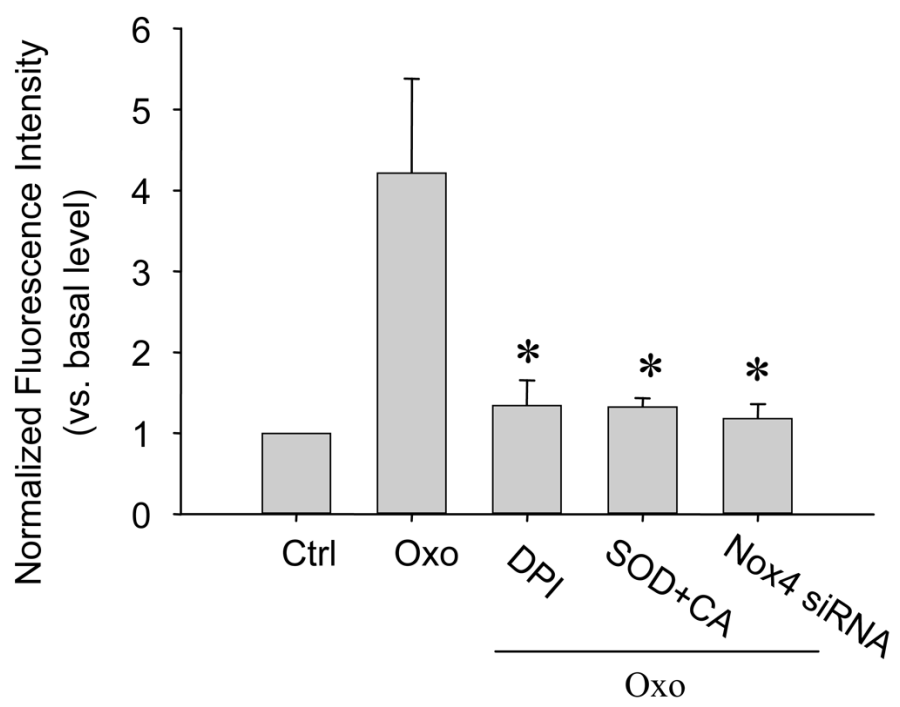

C

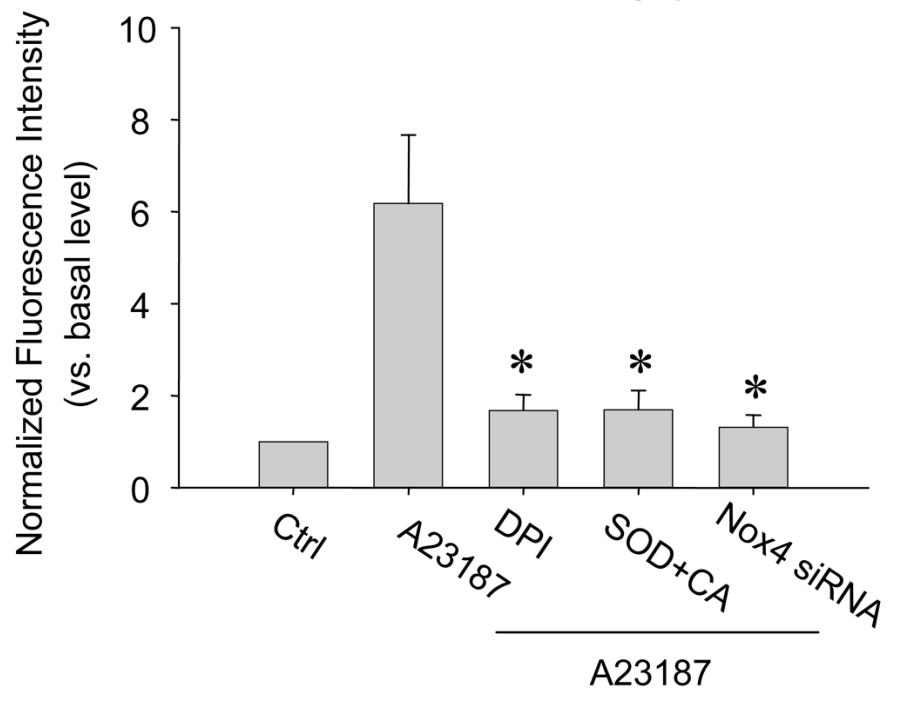

Fig. 2.

Effects of ROS scavengers, NAD(P)H oxidase inhibitor or Nox4 siRNA on SR-derived $\mathrm{O}_{2}{ }^{-}$ production in CAMs by confocal fluorescence microscopy assay. A: Western blot analysis shows knockdown of Nox4 by its siRNA in CAMs. B: Summarized data showing the effects of PEG-SOD, NAD(P)H oxidase inhibitor, DPI and Nox4 siRNA on SR-derived $\mathrm{O}_{2}{ }^{-}$ production induced by Oxo $(80 \mu \mathrm{M})$. C: Summarized data showing the effects of PEG-SOD, $\mathrm{NAD}(\mathrm{P}) \mathrm{H}$ oxidase inhibitor, DPI and Nox4 siRNA on SR-derived $\mathrm{O}_{2}{ }^{-}$production induced by A23187 $(1 \mu \mathrm{M}) . \mathrm{n}=6,{ }^{*} \mathrm{P}<0.05$ compared with Oxo or A23187 alone group. 


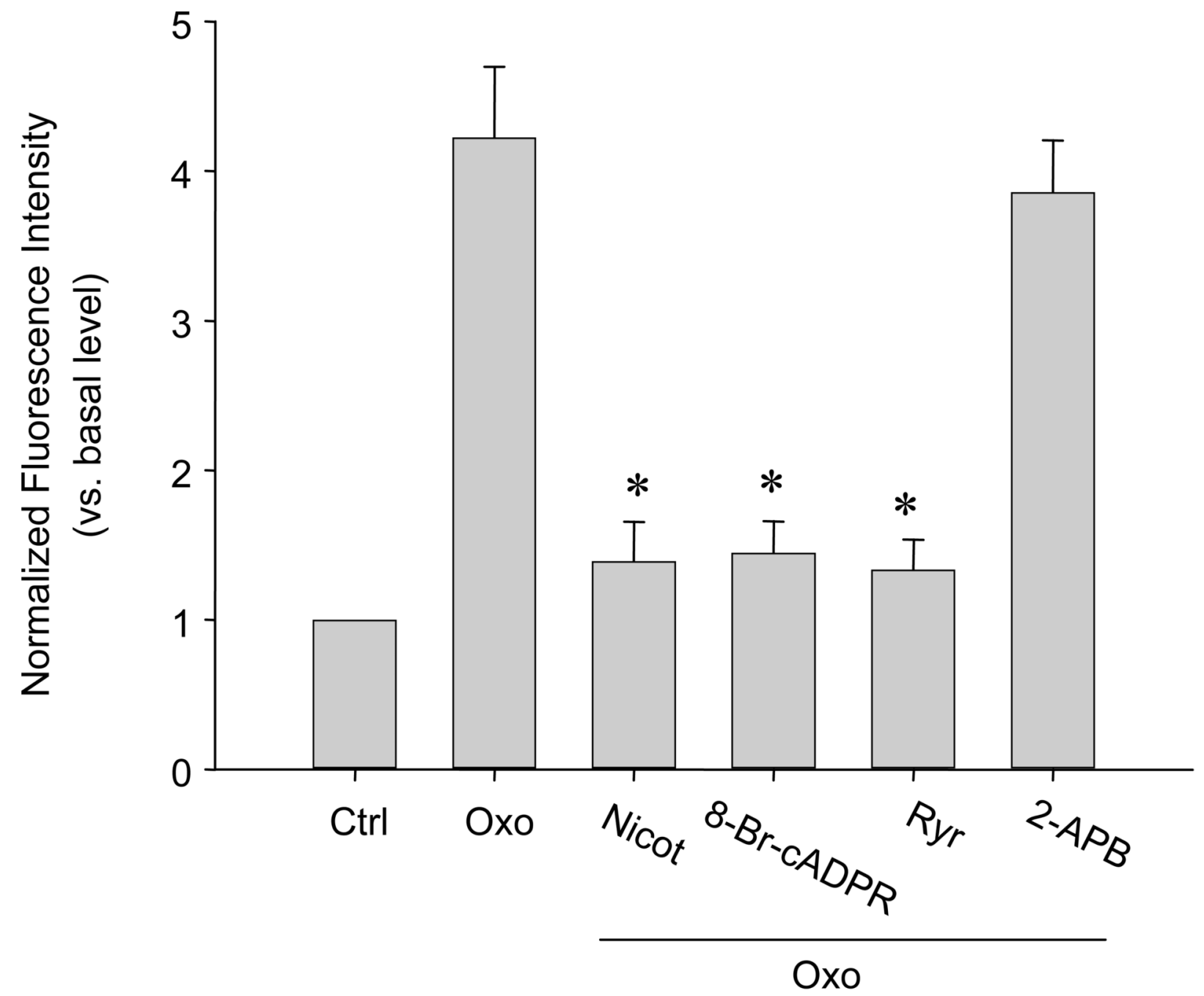

Fig. 3.

Effects of cADPR-RyR/Ca ${ }^{2+}$ signaling pathway inhibition on SR-derived $\mathrm{O}_{2} \cdot{ }^{-}$production in CAMs by confocal fluorescence microscopy assay. ADP-ribosyl cyclase inhibitor, nicotinamide (Nicot.; $6 \mathrm{mM})$, cADPR antagonist, 8-Br-cADPR $(30 \mu \mathrm{M})$, or RyR/Ca ${ }^{2+}$ release channel inhibitor, ryanodine $(\mathrm{Ryr} ; 50 \mu \mathrm{M})$ was used. 2-aminoethoxydiphenyl borate (2-APB; $50 \mu \mathrm{M})$ was also used as an antagonist of $\operatorname{Ins}(1,4,5) \mathrm{P}_{3}$ receptor. $\mathrm{n}=6$, $* \mathrm{P}<0.05$ compared with Oxo alone group. 


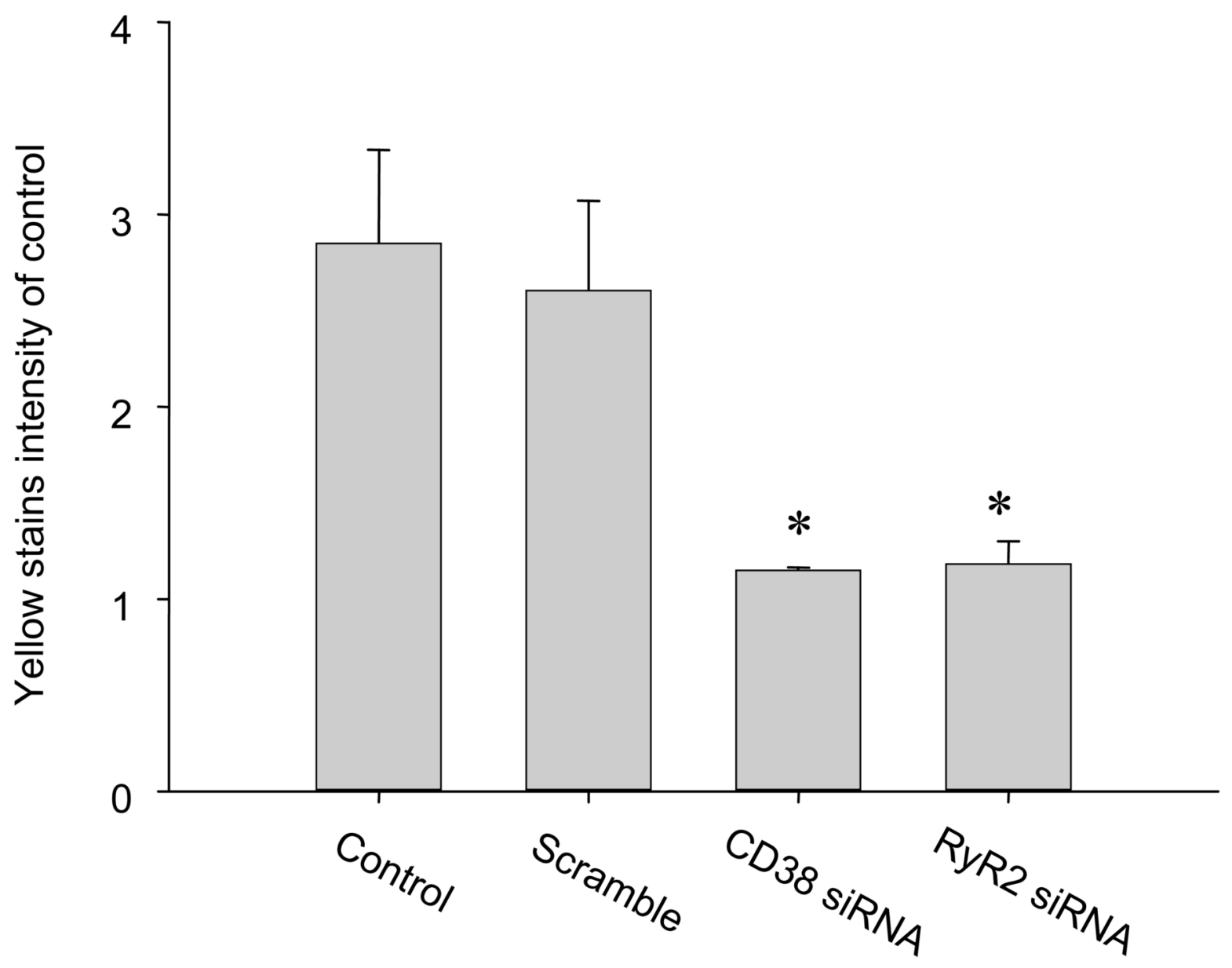

Fig. 4.

Effects of RNA interference of ADP-ribosyl cyclase(CD38) or/and RyR2 gene on SR-derived $\mathrm{O}_{2}{ }^{-}$production in CAMs by confocal fluorescence microscopy. ADP-ribosyl cyclase or RyR2 siRNAs were introduced before experiments using siLentFect ${ }^{\mathrm{TM}}$ lipid followed by $80 \mu \mathrm{M}$ Oxo treatment. $\mathrm{n}=6, * \mathrm{P}<0.05$ compared with control. 

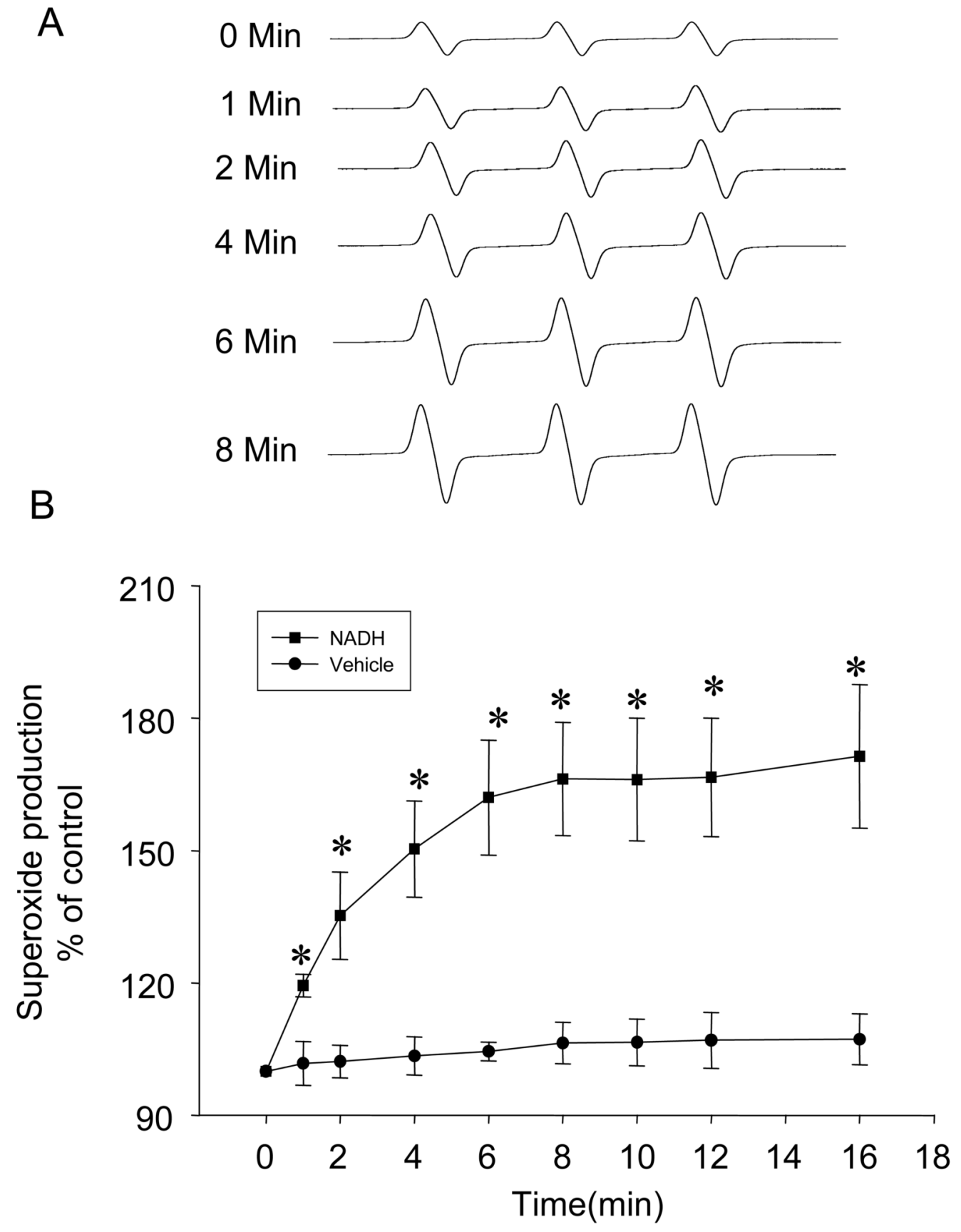

Fig. 5.

Time-dependent $\mathrm{O}_{2}{ }^{-}$production of purified SR from bovine CAMs detected by electron spin resonance (ESR) spectrometry. A: representative ESR spectrograph of $\mathrm{O}_{2} \cdot{ }^{-}$trapped by 1hydroxy-3-methoxycarbonyl-2,2,5,5-tetramethylpyrrolidine (CMH) in the reaction mixture with NADH as substrate. B: Summarized data showing time-dependent increase in $\mathrm{O}_{2} \cdot{ }^{-}$ production from the purified SR. $\mathrm{n}=6, * \mathrm{P}<0.05$ compared with control. 


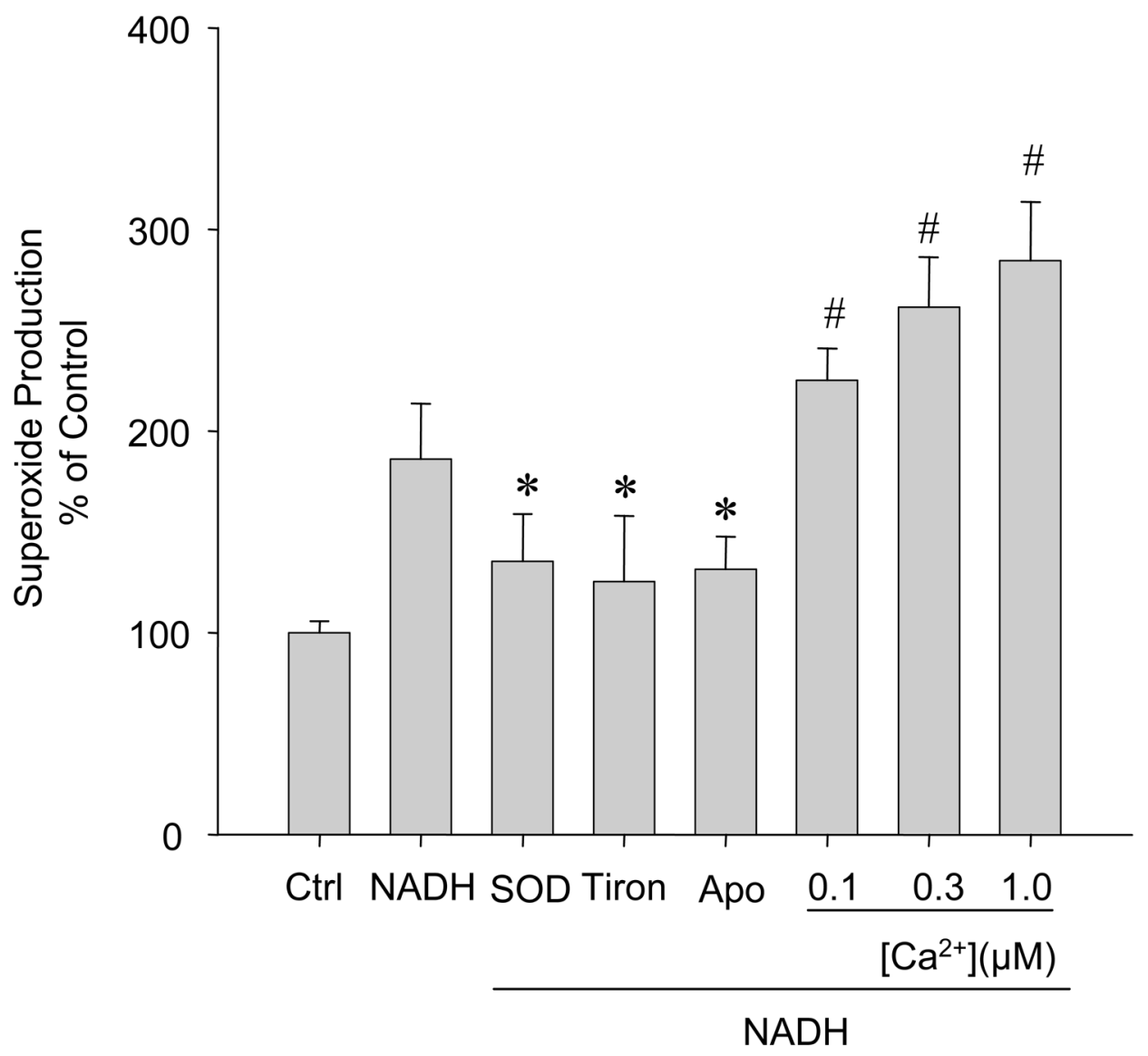

Fig. 6.

Effects of $\mathrm{O}_{2} \cdot{ }^{-}$scavengers, $\mathrm{NAD}(\mathrm{P}) \mathrm{H}$ oxidase inhibitors or $\mathrm{Ca}^{2+}$ dependence on $\mathrm{O}_{2} \cdot{ }^{-}$ production in the purified SR from bovine CAMs by ESR assay. $\mathrm{n}=6,{ }^{*},{ }^{\#} \mathrm{P}<0.05$ compared with NADH alone group. 


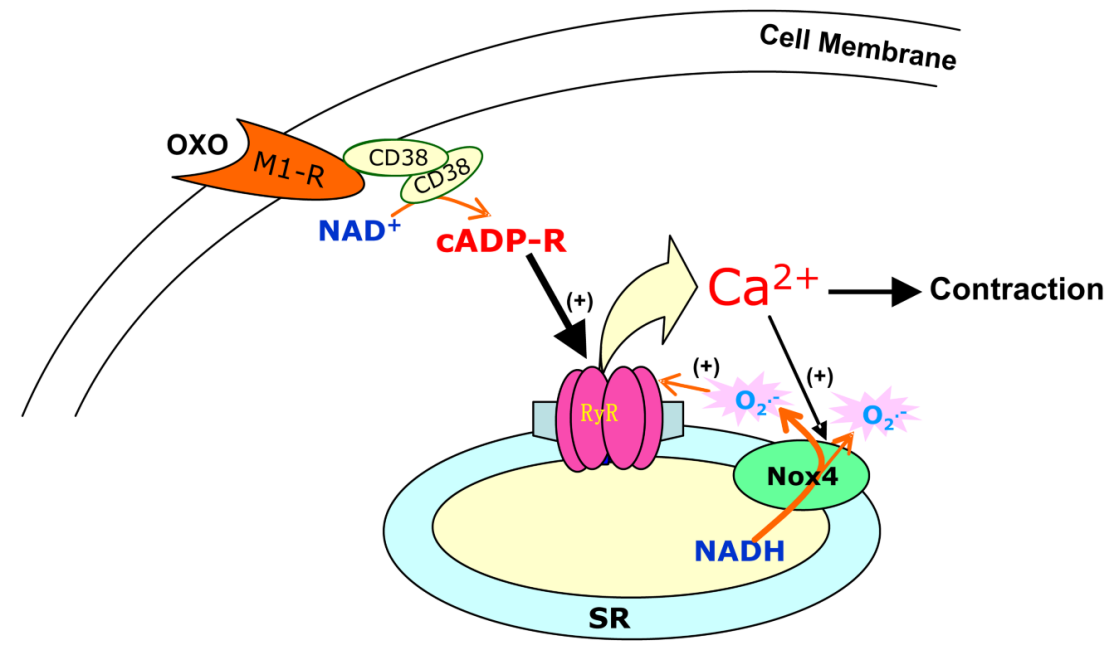

Fig. 7.

A schematic diagram showing our conclusion that $\mathrm{O}_{2}{ }^{-}$is locally produced from Nox4 in the SR of CAMs in response to $\mathrm{M}_{1}$ receptor activation and that this local $\mathrm{O}_{2} \cdot{ }^{-}$production is regulated by cADPR-RyR-Ca ${ }^{2+}$ signaling pathway. Given the great sensitivity of RyRs to redox changes, increased local $\mathrm{O}_{2} \cdot{ }^{-}$level may enhance the activation of these receptors, leading to a feed forward regulation of both redox and $\mathrm{Ca}^{2+}$ signaling in CAMs. 